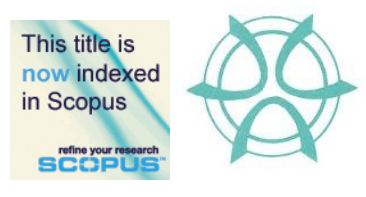

PLANNING MALAYSIA:

Journal of the Malaysian Institute of Planners

VOLUME 16 ISSUE 4 (2018), Page 161 - 175

\title{
ACCESS TO URBAN AGRICULTURAL LAND IN IBADAN, NIGERIA
}

\author{
Bolanle Wahab $^{1}$, Ayobami Popoola ${ }^{2} \&$ Hangwelani Magidimisha ${ }^{3}$ \\ ${ }^{I}$ Department of Urban and Regional Planning \\ UNIVERSITY OF IBADAN NIGERIA \\ ${ }^{2 \& 3}$ Department of Town and Regional Planning, \\ UNIVERSITY OF KWAZULU-NATAL SOUTH AFRICA
}

\begin{abstract}
Efficient allocation of spaces for all activities is a pivot role of planners in human settlements development. The rapid and unplanned growth of Ibadan has limited farmers' access to land for urban agriculture purposes, especially in the urban local government areas (LGAs). This study examined urban farmers' access to land for farming and the activities of local planning authorities in terms of land allocation for farming in Ibadan. A structured questionnaire was administered to 244 urban farmers, while key-informant interviews were conducted with the officials of local planning authorities and departments of agriculture in the urban LGAs in Ibadan. The study revealed that the scarcity of land for farming has subjected over $30 \%$ of the respondents to practice farming on family land, while $17 \%$ farmed on available open spaces, including floodplains; land along mountain ridges; land under power lines, and institutions' lands. The barriers to expanding urban farmland identified by farmers included finance, the unavailability of land in the urban area, neglect of farming and land tenure system. The study recommended the enactment of a planning policy for the classification and integration of agricultural land use as a recognised land use component in urban physical development and zoning plans.
\end{abstract}

Keywords: land scarcity, urban agriculture, zoning, land budgeting 
Bolanle Wahab, Ayobami Popoola \& Hangwelani Magidimisha

Access to Urban Agricultural Land in Ibadan, Nigeria

\section{INTRODUCTION}

Creating sustainable food systems is one of the most compelling challenges of the 21st century. Because of its multi-functional character, food is an ideal medium for designing sustainable places. For these reasons, food planning is now bringing experts and people from diverse range of background together (ISOCARP, 2015; Pothukuchi \& Kaufman, 2000). Thus, in an attempt to bring about a sustainable food system, urban planners need to understand the methods and strategies of producing food. The momentum of advocacy for urban agriculture (UA) all over the globe is a reflection of the need for food within the urban space. Despite the increasing demand for food owing to the rapid rate of urbanization and increasing population, cultivable lands for agriculture are becoming scarce, as urban growth and expansion have been claiming much of the arable lands (wetlands, open spaces, floodplains, agricultural layouts).

Land scarcity is a peculiar characteristic of urban centres in developing nations. Land for agriculture has declined owing to urbanization, and land fragmentation within urban areas. Studies (Headey \& Jayne, 2014; Lal, 2007) have established declines in farm sizes across the globe and Africa. Lwasa et al. (2011) claim that inadequate space for farming is a limitation to food production in Africa. Data source countries such as Ethiopia, Kenya, Malawi, Uganda and Rwanda are experiencing a decline in farm size (Jayne, Chamberlin \& Headey, 2014). Decline in farm sizes from 2.5 hectares (ha) in the year 1994 to 1.4 ha in 2010 and 0.85 ha in 2013 have been reported in Nigeria (Food and Agriculture organisation-FAO, 2017; Headey \& Jayne, 2014).

Atu, Offiong, Eni, Eja and Esien (2012) aver that urban sprawl has been a common event and still remains one of the greatest threats facing agricultural lands in Nigeria. Abiodun and Bayode (2014) assert that the rate of development of land (from $42 \%$ built-up in 1989 to $70 \%$ built up in 2013) in the Ibadan metropolis is a reflection of urban land consumption. The consequence of which is a decline in food production within the urban space owing to inadequate access to land for farming and induced land price inflation which has hindered poor urban farmers from acquiring land for farming and commercialization of urban farmland by fairly rich urban farmers. Lwasa et al. (2013) observe that one of the factors that continuously constraints agricultural activities is competition from other land uses/inadequate access to land, urbanisation and city expansion.

To attend to food demand and city growth several authors iterate the introduction land use zoning as an effective and responsive police planningoriented device that can be used by local governments towards efficient urban outcomes, open space integration for UA and proper spatial arrangements which is inclusive of agricultural land use in physical development plans being prepared by planning authorities (Bickerdike, DiLisio, Haskin, McCullagh, \& PierceQuinonez, 2010; Al-Chalabi, 2008). Ibadan's continued spatial and demographic growth and lack of a development plan as at December 2017 promotes disorderly 
land use and the unhealthy physical development of fragile and risk-prone areas, such as wetlands, floodplains, steep slopes, urban vegetation and other areas that are suitable for agriculture.

It is argued by Sauer et al. (2008) and Foley et al. (2005) that the future supply of food and agriculture is faced with the challenges of decreasing rates because of physical limits. Managing land and land allocation for activities remains the duty of urban planners. In Nigeria, urban agricultural land has not been properly delineated by local planning authorities. In Ibadan, urban agriculture (UA) remains an incidental activity which is undertaken as a temporary activity within any used land spaces, pending their use for the designated development purposes. This is so because UA is not a recognised urban land use and there is no statutory provision in physical plans at any scaleresidential site plan, neighbourhood district plan and city master plan. Nonetheless planning as a locally-driven process and a shared community-based vision of the future should include agricultural activities by recognizing the value of agriculture as a land use and a business.

Planning for agriculture establishes a framework for an economically and environmentally sustainable agricultural industry. It steers growth away from active farming communities; reduces regulatory barriers; encourages policies that support appropriate infrastructure development and new farming opportunities; and addresses farm tenure and transfer. It is against this backdrop that this study examined access to urban agricultural land amongst city farmers and also identified the present and expected role of local planning authorities on urban agriculture in Ibadan.

\section{THE STUDY AREA}

Ibadan is one of the major urban centres in Nigeria with an urban land area of about $463.33 \mathrm{~km}^{2}$. The city is made up of 11 local government areas (LGAs) out of which five (5) are urban LGAs (Figure 1) with an urban population of $1,338,659$ and estimated at $6,017,709$ in 2016 and projected to be 11.32 million by 2036, at a $3.5 \%$ annual growth (Dar-Al-Handasah, 2018).

Studies (Adelekan, Olajide-Taiwo, Ayorinde, Ajayi, \& Babajide, 2014; Bankole \& Bakare, 2011) established that the city's growth became exponential in the year 2000. The built-up area of Ibadan increased from 100 ha in 1830 to $448.56 \mathrm{~km}^{2}$ in 2006 and $491.21 \mathrm{~km}^{2}$ in 2013 at an average annual rate of $2.8 \%$ since the year 2000. The city's physical expansions owing to fast-growing commercial and industrial activities, has resulted in a decline in agricultural land within the urban and peri-urban areas (Fourchard, 2003).

Dar-Al-Handasah (2018) reports that with the manufacturing sector of Ibadan stagnant, agriculture which remains a means of household livelihood for residents of Ibadan should be invested in and also supported to meet employment demand. Dar-Al-Handasah (2018) avers that urban agricultural activities, which 
Bolanle Wahab, Ayobami Popoola \& Hangwelani Magidimisha

Access to Urban Agricultural Land in Ibadan, Nigeria

include land used for growing crops, raising cattle, urban agriculture and any associated function (such as farm buildings and storage), practised along the banks of rivers or drainage channels contribute $8 \%$ of the total employment in Ibadan. Within the $8 \%$ of total employment, farming was often engaged as a complementary income source (to trading, teaching and artisanship) or household food security (Wahab \& Popoola, 2018). Urban farmers in Ibadan often engage in the planting of food crops; vegetable and legumes; small scale tuber crops; and the rearing of animals (Wahab \& Popoola, 2018; Odewumi, Awoyemi, Iwara, \& Ogundele, 2013).

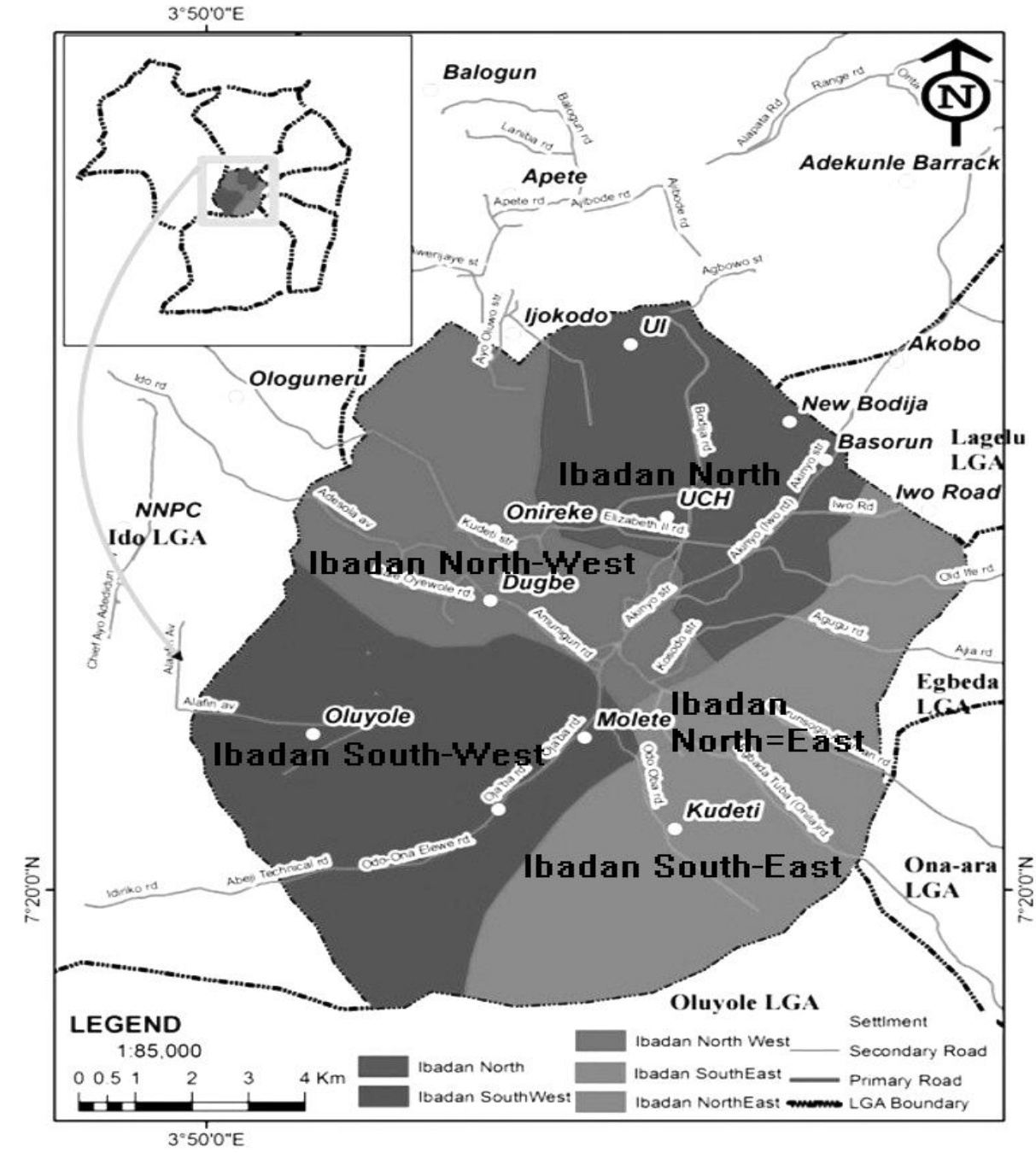

Figure 1: Five urban local government areas in the context of Ibadan Metropolis Source: Department of Geography, University of Ibadan (2018) 


\section{MATERIALS AND METHODS}

This survey-based study utilized quantitative data collected through a structured questionnaire administered to urban farmers. The questions were both open (for example, source of land) and closed-ended (such as the reason for displacement). Key-informant interviews were conducted with officials of local planning authority and department of agriculture in the five (5) LGAs. The questionnaire was administered using the mixed method, comprising purposive, snow ball, convenience and accidental sampling techniques. Trained field assistants who could speak both English and the native language of the farmers, administered the questionnaire. At the end of each day of the fieldwork, completed copies of the questionnaire were checked for any unclear responses.

The sample frame for the study was the 4,073 farmers registered with the Oyo State Agricultural Development Project (OYSADEP) in the five urban LGAs (Ibadan North, Ibadan North-East, Ibadan North-West, Ibadan South-East, and Ibadan South-West). A 6\% sample size representing 244 urban farmers was adopted for the administration of the structured questionnaire in the 5 LGAs, as shown in Table 1. The study took into consideration the least-cost approach, ease of accessibility and cluster sample technique employed by Odewumi et al. (2013), and Wahab and Popoola (2018) to arrive at the 6\% sample size. The availability of urban farmers and accessibility to urban farmers were some factors considered in selecting the sampled respondents across the study area. Due consideration was given to ethical issues, such as the respondents' right to answer or decline questions, purpose of the study and confidentiality of the responses given.

Table 1: Sample Size

\begin{tabular}{lcc} 
Local Government Area & No. of Registered Farmers & Sampled Farmers (6\%) \\
\hline Ibadan North & 1256 & $\mathbf{7 5}$ \\
Ibadan North-East & 605 & $\mathbf{3 6}$ \\
Ibadan North-West & 462 & $\mathbf{2 8}$ \\
Ibadan South-East & 930 & $\mathbf{5 6}$ \\
Ibadan South-West & 820 & $\mathbf{4 9}$ \\
\hline TOTAL & 4073 & 244 \\
\hline
\end{tabular}

Source: Authors

\section{RESULTS AND DISCUSSIONS}

\section{Urban Agriculture and Access to land}

Key informant interviews conducted with the officials of the town planning authorities and department of agriculture in the five (5) urban local government areas revealed that urban planners perceived farming as an activity for the rural areas. They viewed their duty towards sustaining urban agriculture in Ibadan as being limited to the designation of accessible routes to various farms, thereby neglecting land budgeting and allocation for agricultural purposes in their various 
Bolanle Wahab, Ayobami Popoola \& Hangwelani Magidimisha

Access to Urban Agricultural Land in Ibadan, Nigeria

developmental plans. As stated by a local planning official “...outside providing them (urban farmers) with roads...I don't believe the allocation of space for UA in Ibadan is feasible...considering the increasing demand for land for other economic land uses like commercial and residential."

The findings on sources of land for farming (Table 2) revealed that $31.4 \%$ of the respondents made use of family land to farm, $16.4 \%$ used inherited lands, $16.8 \%$ farmed on unused open spaces; $18.9 \%$ used leased land; $15.2 \%$ made use of government land; while the remaining $1.2 \%$ respondents farmed on their own personally acquired land. Government lands in use for farming were those undeveloped spaces at the Forest Research Institute of Nigeria (FRIN), National Horticultural Research Institute (NIHORT), University College Hospital, Nigerian Army Barracks and the University of Ibadan (see Figure 2). Interviews revealed that stipends of between $\$ 5000$ (\$17) to $\$ 10000$ (\$34) ( $\$ 300=1 \mathrm{USD}$ ) were paid as royalty on leased lands and also on government lands, such as that of FRIN, while private individuals and the military barracks leased out their lands as a measure of controlling weeds in their environment.

Unlike government dedicated lands for farming that are subject to the payment of stipends by urban farmers, interviews reflected that communal lands which can either be inherited or owned by the family is subject to the payment of royalties as demanded by the family head or arrangements arrived at during collective family meetings. Findings from interviews with farmers on such lands revealed that land users, which can be a member of the family or an outsider, may be required to pay a token of less than $\$ 5000$ (\$17) per annum for the use of the land, or may sometimes make use of the land for free without payment but be required to adequately prevent the land from excess weed or external land fraudsters in the area sell lands that does not belong to their families or communities. This establishes that land utilization by farmers can be based on monetary arrangements or the rendering of desired services.

Table 2: Source and ownership of land for farming

\begin{tabular}{lcc}
\hline Source & No. of Respondents & $\%$ \\
\hline Family land & 77 & 31.4 \\
Leased land & 46 & 19 \\
Unused open space & 41 & 16.8 \\
Inherited land & 40 & 16.4 \\
Government land & 37 & 15.2 \\
Others & 3 & 1.2 \\
\hline Total & 244 & 100.0 \\
\hline
\end{tabular}


PLANNING MALAYSIA



Figure 2: Spatial distribution of locations where urban agriculture is prominent in Ibadan

Source: Authors

The study hypothesized that there is no significant relationship between farm size and average monthly income using the Pearson Moment Correlation statistical tool. The test showed a positive relationship between average monthly income and farm size. The analysis is presented in Table 3. 
Bolanle Wahab, Ayobami Popoola \& Hangwelani Magidimisha

Access to Urban Agricultural Land in Ibadan, Nigeria

Table 3: Symmetric measures test of relationship between farmers' income and farm

\begin{tabular}{|c|c|c|c|c|c|}
\hline & & Value & $\begin{array}{c}\text { Asymp. Std. } \\
\text { Error }^{\mathrm{a}}\end{array}$ & Approx. T $^{\mathrm{b}}$ & $\begin{array}{c}\text { Approx. } \\
\text { Sig. }\end{array}$ \\
\hline $\begin{array}{c}\text { Interval by } \\
\text { Interval }\end{array}$ & Pearson's r & .329 & .054 & 5.421 & $.000^{\mathrm{c}}$ \\
\hline $\begin{array}{c}\text { N of Valid } \\
\text { Cases }\end{array}$ & & 244 & & & \\
\hline
\end{tabular}

A correlation analysis of the test of the relationship between income and farm size established a weak positive relationship with a significant difference at $\mathrm{r}$-value $=0.329, p=0.319$. The profile showed a relationship $(\mathrm{r}=0.329, \mathrm{n}=244$, $\mathrm{p}<0.000$ ) between the income of farmers and farm size within the urban setting. The correlation was statistically significant at 0.000 , which indicated that there was a statistically significant relationship between farm size and farmers' income, as farmers' income accounted for a $30 \%$ change in farm size. This is in fact support of the argument that financial strength and capital access remain relevant to urban agriculture and land accessibility. However, other factors were not taken into consideration as to what explains farm sizes.

Despite the vast area of land within Ibadan city, agricultural land-use has limited access to land. Table 4 indicates that $54.1 \%$ (132 farmers) of the farmers did not have adequate land for farming, while the remaining $45.9 \%$ (112 farmers) had adequate farm land for farming. Adequacy of land was seen as the perception of a farmer's farming capacity and ability as against the land available for farming. Of the farmers with no adequate access to land for farming, $32.6 \%$ had at one time or the other been displaced from the land they used for farming. This established that 3 out of 5 sampled farmers with inadequate farm land for farming had been subjected to land and livelihood stress owing to farmland displacements by other urban developments.

The cross-tabulation of urban farmers' income and farmers' history of displacement in Ibadan presented in Table 4 revealed that income did not dictate farmers' history of displacement. A chi-square test value of 0.489 (which is higher than $0.05 \%$ ) was also obtained to buttress this assertion. This meant that there was over a $95 \%$ confidence level in the prediction. In other words, as far as urban farmers' average monthly income and history (account) of displacement were concerned, there was no significant variation in displacement. This points to the fact that, farmers' income in Ibadan does not necessarily translate to their being displaced as, often (as narrated by an urban farmer), other land uses outbid the agricultural land when priced. The distribution of displaced farmers shows a higher percentage (29 farmers) in Ibadan North, Ibadan NE (12) and Ibadan SE (14) respectively. These LGAs, according to Popoola, Ayangbile and Adeleye (2015), are high-density commercial and residential areas of Ibadan city. 
PLANNING MALAYSIA

Journal of the Malaysia Institute of Planners (2018)

Table 4: Cross-tabulation of farmers' income and the history of farm displacement

\begin{tabular}{|c|c|c|c|c|c|c|c|c|}
\hline \multirow{2}{*}{\multicolumn{2}{|c|}{$\begin{array}{c}\text { Displacement } \\
\text { history by } \\
\text { LGAs }\end{array}$}} & \multicolumn{6}{|c|}{ Income Distribution of farmers } & \multirow[b]{2}{*}{ Total } \\
\hline & & $\begin{array}{c}< \\
\$ 5000\end{array}$ & $\begin{array}{l}\text { N5000- } \\
\$ 15000\end{array}$ & $\begin{array}{l}\text { N16000- } \\
\$ 25000\end{array}$ & $\begin{array}{l}26000- \\
\$ 35000\end{array}$ & $\begin{array}{c} \\
N 36000- \\
\$ 45000\end{array}$ & $\begin{array}{c}> \\
¥ 45000\end{array}$ & \\
\hline \multirow{6}{*}{ YES } & $\begin{array}{l}\text { Ibadan } \\
\mathrm{N}\end{array}$ & 3 & 4 & 5 & 9 & 1 & 7 & 29 \\
\hline & $\begin{array}{l}\text { Ibadan } \\
\text { NE }\end{array}$ & 1 & 0 & 5 & 4 & 2 & 0 & 12 \\
\hline & $\begin{array}{l}\text { Ibadan } \\
\text { NW }\end{array}$ & 0 & 1 & 0 & 1 & 1 & 0 & 3 \\
\hline & $\begin{array}{l}\text { Ibadan } \\
\text { SE } \\
\end{array}$ & 0 & 1 & 6 & 3 & 1 & 3 & 14 \\
\hline & $\begin{array}{l}\text { Ibadan } \\
\text { SW }\end{array}$ & 0 & 1 & 1 & 4 & 1 & 1 & 8 \\
\hline & Total & 4 & 7 & 17 & 21 & 6 & 11 & 66 \\
\hline \multirow{6}{*}{ NO } & $\begin{array}{l}\text { Ibadan } \\
\mathrm{N} \\
\end{array}$ & 4 & 10 & 10 & 12 & 3 & 7 & 46 \\
\hline & $\begin{array}{l}\text { Ibadan } \\
\text { NE }\end{array}$ & 0 & 5 & 3 & 5 & 1 & 10 & 24 \\
\hline & $\begin{array}{l}\text { Ibadan } \\
\text { NW }\end{array}$ & 0 & 4 & 6 & 12 & 3 & 0 & 25 \\
\hline & $\begin{array}{l}\text { Ibadan } \\
\text { SE }\end{array}$ & 2 & 8 & 16 & 3 & 5 & 8 & 42 \\
\hline & $\begin{array}{l}\text { Ibadan } \\
\text { SW }\end{array}$ & 1 & 5 & 8 & 9 & 3 & 15 & 41 \\
\hline & Total & 7 & 32 & 43 & 41 & 15 & 40 & 178 \\
\hline \multicolumn{9}{|c|}{ Chi-square analysis of income and history of farm displacement amongst urban farmers } \\
\hline \multirow{2}{*}{\multicolumn{2}{|c|}{$\begin{array}{l}\text { Pearson Chi- } \\
\text { Square }\end{array}$}} & Value & Df & \multicolumn{2}{|c|}{ Asymp. Sig. (2-sided) } & & & \\
\hline & & $4.434^{\mathrm{a}}$ & 5 & .489 & & & & \\
\hline \multicolumn{2}{|c|}{$\begin{array}{l}\text { Likelihood } \\
\text { Ratio } \\
\end{array}$} & 4.520 & 5 & .477 & & & & \\
\hline \multicolumn{2}{|c|}{$\begin{array}{l}\text { Linear-by- } \\
\text { Linear } \\
\text { Association } \\
\end{array}$} & .039 & 1 & .844 & & & & \\
\hline \multicolumn{2}{|c|}{$\begin{array}{l}\mathrm{N} \text { of Valid } \\
\text { Cases }\end{array}$} & 244 & & & & & & \\
\hline
\end{tabular}

When queried further, some of the urban farmers reported that they often resorted to floodplain areas, unused and unclaimed open spaces and mountain strips for farming within urban areas, while some claimed to have relocated to rural areas or changed to other occupations such as security inorder to carter for their households' livelihood. The urban land struggle remains the order within the urban space as it has been from time immemorial. As Lasisi, Popoola, Adediji, Adedeji and Babalola (2016), and Taiwo (2010) notes, the spatial increase in the area extent of built-up areas of cities is fast engulfing non-urban land uses within and outside urban spaces. 
Bolanle Wahab, Ayobami Popoola \& Hangwelani Magidimisha

Access to Urban Agricultural Land in Ibadan, Nigeria

With this increasing population and diminishing land area for farming, it is becoming more important for farmers to utilize their limited land resources to produce enough food to feed the city. Some of the barriers to expanding farmland as identified by urban farmers include finance (30.3\%); the unavailability of land in the urban area (17.6\%); a rapid rate of urbanization $(9.4 \%)$; the neglect of farming $(4.5 \%)$; family and communal tenure systems (1.6\%); and other factors, which included political manipulation, old age of farmers, family decisions and the effect of remittance by children.

Field evidence shows farmers do not have rights to the land they cultivate as they are ejected from corporate and government unused open spaces without notice. Farmers' insecure status discourages investment in permanent structures, such as fencing, wells with concrete walls and perennial crop production. Interviews with 66 displaced urban farmers in this study revealed that at one time or other, the respondents had been displaced from their places of farming. The reasons included urban development, owners' decisions to use the land, land ownership crises, preferences for another activities such as mechanic and blockmaking industries and, in some cases, no solid reason.

\section{Urban Agriculture and Urban Planning}

Lwasa et al. (2013) assert that urban agriculture is in direct competition with other potential urban land uses. The cases of displacement of urban farmers from the land they farmed on can be traced to a lack of designation and the lack of allocation of land for agricultural activities by urban planners.

Interviews conducted across the local planning authorities in the five (5) urban local government areas revealed that the local government areas did not have master (development) plans and the planning authorities did not designate land for agriculture in their local (layout) plans. Town planning officials argued that uses for land in the urban LGAs were mainly commercial and residential purposes. They opined that planners could only support agricultural activity through proper planning for accessibility through road construction to link the rural areas where primary production activities take place. Farmers identified reasons for the lack of agricultural land for farming in the local government areas as urbanization, neglect of the agricultural sector owing to the oil boom and a lack of political will. A majority $(77.5 \%)$ of the sampled urban farmers still argued that agriculture should be recognised as an important urban land use activity by the physical planning authority and that they be allocated adequate land to promote urban food security, urban livelihood and biodiversity. A local planning authority official said:

"We (planning officials) are not against them (urban farmers) practicing UA... but land is competitive and expensive in the urban area... which most of them cannot afford to own. For the few who can get access to land, it is usually done on household unused lands and some semi-public or restricted areas (open spaces, 
derelict land, institutional lands) which is also subjected to efficient communal rules and demands".

During the key informant interviews, the officials of local planning authorities in Ibadan North East and Ibadan North-West LGAs stressed that urban agriculture was not a recognised land use in their LGAs. They claimed that residential and commercial uses were the main function of urban lands and that agricultural activity were expected to be practised in the rural areas. Therefore, less priority was given to urban agriculture by the government officials. In contrast, officials of the three other local planning authorities (Ibadan SouthWest, Ibadan South-East and Ibadan North) claimed that urban agriculture was a recognised urban land use activity. Notwithstanding their present stance on urban agriculture in the LGA, all interviewed officials expressed a willingness to advocate for the integration of agriculture into urban land use and future plans. Doing this, according to one official,

$$
\begin{aligned}
& \text { “...will promote urban food security, increase household/individual nutrition } \\
& \text { among residents, create jobs and improve livelihood". }
\end{aligned}
$$

The change in land use and dynamic characteristics of urban centres across the globe are factors that define the outlook, functionality and survival of cities. Owing to these changes in city characteristics, changes in the pattern of land allocation for urban activities becomes imperative. An official was asked if there was ever any land allocation for UA in the urban LGA. He asserted thus:

“...I don't know if there was land allocated for UA before in this LGA. Even if there was, I am sure it would have been converted for another land-use activity that attracts higher economic returns...except for floodplains"

Findings from the Ministry of Lands, Survey and Housing revealed the conversion of agricultural land for other land uses (Table 5), which are considered to be more economical than urban agriculture. This can be attributed to the nodal location of many of these lands.

Table 5: Instances of agricultural land conversion in Ibadan

\begin{tabular}{|l|l|l|l|l|}
\hline Location & $\begin{array}{l}\text { LGA } \\
\text { located }\end{array}$ & $\begin{array}{l}\text { Land } \\
\text { Size }\end{array}$ & $\begin{array}{l}\text { Year of } \\
\text { conversion }\end{array}$ & Land-use converted to and owner \\
\hline $\begin{array}{l}\text { Along Ibadan Lagos } \\
\text { Expressway, Ibadan }\end{array}$ & Ibadan N & $\begin{array}{l}100 \\
\mathrm{Ha}\end{array}$ & 2013 & $\begin{array}{l}\text { From crop farming use to educational } \\
\text { (lbadan Technical University) }\end{array}$ \\
\hline $\begin{array}{l}\text { Dairy Farm Iwo road- } \\
\text { Monatan Area, Ibadan }\end{array}$ & Ibadan NE & $\begin{array}{l}80 \\
\mathrm{Ha}\end{array}$ & 1999 & $\begin{array}{l}\text { From dairy farm to residential (Kolapo } \\
\text { Ishola Government Residential Estate) }\end{array}$ \\
\hline $\begin{array}{l}\text { BOVAS Petrol } \\
\text { Station along New } \\
\text { Oyo Express way }\end{array}$ & Ibadan N & $\begin{array}{l}0.15 \\
\mathrm{Ha}\end{array}$ & 2000 & $\begin{array}{l}\text { Farming use to BOVAS Petrol Filling } \\
\text { Station }\end{array}$ \\
\hline Ibadan Circular Road & $\begin{array}{l}\text { Metropolitan } \\
\text { Ibadan }\end{array}$ & $\begin{array}{l}100 \\
\mathrm{Ha}\end{array}$ & 2005 & $\begin{array}{l}\text { From incidental agriculture to } \\
\text { circulation (Ibadan Circular Road) }\end{array}$ \\
\hline
\end{tabular}


Bolanle Wahab, Ayobami Popoola \& Hangwelani Magidimisha Access to Urban Agricultural Land in Ibadan, Nigeria

\begin{tabular}{|l|l|l|l|l|}
\hline $\begin{array}{l}\text { The Lord Reigneth } \\
\text { Estate, off } \\
\begin{array}{l}\text { Iseyin/lbadan Road, } \\
\text { Ijaye }\end{array}\end{array}$ & $\begin{array}{l}\text { Ibadan N- } \\
\text { Akinyele } \\
\mathrm{Ha}\end{array}$ & 2012 & $\begin{array}{l}\text { Farming use to residential and } \\
\text { commercial estate (Christian Union Old } \\
\text { Students Association (CUOSA) } \\
\text { Investment Board, Lord Reigneth } \\
\text { Estate) }\end{array}$ \\
\hline $\begin{array}{l}\text { Emmanuel College } \\
\text { Wetland, Samonda, } \\
\text { Along Sango-UI Road }\end{array}$ & Ibadan N & $5 \mathrm{Ha}$ & 2015 & $\begin{array}{l}\text { Collective Farming use to enclosed } \\
\text { unused space } \\
\text { (Emmanuel College of Theology) }\end{array}$ \\
\hline Sango Floodplain & Ibadan NE & 10 & 2015 & $\begin{array}{l}\text { Legume farming use to enclosed unused } \\
\text { space }\end{array}$ \\
\hline $\begin{array}{l}\text { Eleyele/FRIN reserve } \\
\text { Ha }\end{array}$ & Ibadan NW & $11-20$ & 2000 & $\begin{array}{l}\text { Forest reserve, arable, legume and food } \\
\text { crop farming use to commercial } \\
\text { encroachment, religious land use, } \\
\text { residential encroachment (Forest } \\
\text { Research Institute of Nigeria -FRIN) }\end{array}$ \\
\hline $\begin{array}{l}\text { Premier Strip farming } \\
\text { zone, Ajibade- } \\
\text { Dandaru Road }\end{array}$ & Ibadan N & $2 \mathrm{Ha}$ & 2016 & $\begin{array}{l}\text { Food crop farming use religious and } \\
\text { commercial land use (Proposed 5-Star } \\
\text { hotel and religious institutions) (Oyo } \\
\text { State Government) }\end{array}$ \\
\hline $\begin{array}{l}\text { UI-Ajibode farming } \\
\text { zone }\end{array}$ & Ibadan N & $30 \mathrm{Ha}$ & 2015 & $\begin{array}{l}\text { Food crop and legume farming use to } \\
\text { residential and educational land use } \\
\text { (University of Ibadan). }\end{array}$ \\
\hline
\end{tabular}

Source: Authors

The issue of land for urban agriculture in Ibadan metropolis was taken up with an official of the department of agriculture in one of the LGs. He stated thus:

"... although we have practising urban farmers in the LGA, only a few of them were registered with the department and we don't have their (urban farmers') records... so it is actually difficult and impossible to provide land for them..."

This finding depicts the relevance of database management amongst urban agriculture responsibility agencies. Another official reported that:

“...urban farmers were being encouraged to migrate to the periurban and rural areas..."; “... we (government) have acquired land at Egbeda (a rural LGA in Ibadan) that we will allocate to farmers who request for such..."

How farmers often faired in the aftermath of displacement or relocation to rural acquired lands as identified by the official was not extensively investigated in this study. Although the interview with the official reported a basic stipend of $\$ 5000$ (15USD) paid per planting season a year by the farmers on every 1 hectare of land. 
PLANNING MALAYSIA

Journal of the Malaysia Institute of Planners (2018)

\section{CONCLUSION AND RECOMMENDATIONS}

Animal and crop farming within the urban areas remain a vital source of food for city dwellers and income for urban farmers. It is also a strategy to complement the activities in rural food-producing zones. Despite the relevance of urban farming, urban agricultural land use remains less relevant to physical planners and, perhaps, of less priority in Nigeria. Thus, farmers within the city area depend on open spaces, vulnerable areas and floodplains for their farming. However, these are grossly inadequate, thus limiting farmer's access to land for farming purposes.

This study concludes that, for food to be available for human consumption within the urban space, urban agriculture needs to be wellintegrated into the urban economy. An important defining factor for this to translate into improved food security within the city areas is for cultivable land to be protected and available within the urban areas. Based on the findings of this study, the following recommendations become important:

For continuing food production, there is urgent need for the enactment of a planning policy for the classification and integration of agricultural land use as a recognised land use component in urban and rural physical development and zoning plans to facilitate land budgeting by planning agencies for urban farming activities. Statutory provision of land must be made for agricultural activities in physical plans at any scale-residential site plan, neighbourhood district plan and city master plan. There is also the need for heavy investment in floodplain management in Ibadan, as these locations are often classified as automatic areas of relocation some of the displaced farmers. The Bureau of Physical Planning and Development Control needs to strictly enforce the regulation governing open space and floodplain management for strict and proper utilization for farming.

Controlled urbanization and a rigid adherence to development plans by local planning authorities will also help curtail the "rampant disappearance" and uninformed/irrational conversion of agricultural land, as well as control the level of encroachment onto agricultural lands by other urban land uses.

It is imperative that urban planners recognize farming activity as an urban land use component. Improved awareness on the roles played by urban agriculture within the urban development plan and space biodiversity is required and should be pursued by relevant government departments and agencies in collaboration with relevant NGOs and community groups.

The frequent cases of farm clearance by urban land owners can be resolved through proper land use agreements and dialogue between land owners and land users (farmers) through proper land agreement documentation. Land formalization for urban agriculture remains the way through which urban farmers can help secure their lands in the face of increasing economic interests provided by other land uses. 
Bolanle Wahab, Ayobami Popoola \& Hangwelani Magidimisha

Access to Urban Agricultural Land in Ibadan, Nigeria

\section{REFERENCES}

Abiodun, O. \& Bayode, T. (2014). Monitoring and modeling of urban sprawl, case study of Ibadan inner city. International Journal of Remote Sensing and GIS, 3(4), 6471.

Adelekan, I., Olajide-Taiwo, L., Ayorinde, A., Ajayi, D., \& Babajide, S. (2014). Building urban resilience: Assessing urban and peri-urban agriculture in Ibadan, Nigeria. In J. Padgham, and J. Jabbour (Eds.), Nairobi, Kenya: United Nations Environment Programme (UNEP). Retrieved from http://www.start.org/upa/ibadan.pdf.

Al-Chalabi, M. (2008). Somerville's green infrastructure project. Retrieved from http://www.groundworksomerville.org/wp-content/uploads/2010/02/Chalabi. FinalReport20081.pdf.

Atu, J, Offiong, R. Eni, D. Eja, I., \&Esien, O. (2012). The effects of urban sprawl on peripheral agricultural lands in Calabar, Nigeria. International Review of Social Sciences and Humanities, 2(2), 68-76.

Bankole, M. \& Bakare, H. (2011). Dynamics of urban land use changes with remote sensing: Case of Ibadan, Nigeria. Journal of Geography and Regional Planning, 4(11), 632-643.

Bickerdike, C., DiLisio, C., Haskin, J., McCullagh, M., \& Pierce-Quinonez, M. (2010). From factories to fresh food planning for urban agriculture in Somerville. Retrieved from https://www.farmlandinfo.org/sites/default/files/ Planning_for_Urban_Ag_in_Somerville_Final_Report_1.pdf.

Dar-Al-Handasah (2018, May 18). Ibadan City Master-plan. Retrieved from www.ibadanmasterplan.com.

Foley, J. A., Defries, R., Asner, G. P., Barford, C., Bonan, G., Carpenter, S. R., ...\& Gibbs, H.K. (2005). Global consequences of land use. Science, 309(5734), 570-574.

Food and Agriculture Organization (FAO), (2017, April 11). Small family farms data portrait basic information document methodology and data description. Retrieved from http://www.fao.org/fileadmin/user_upload/smallholders _dataportrait/docs/Data_portrait_variables_description_new2.pdf.

Fourchard, L. (2003). Urban slums reports: The case of Ibadan, Nigeria. Ibadan, Nigeria: Institut Francais de Rechercheen Afrique. (IFRA), University of Ibadan.

Headey, D., \& Jayne, T. (2014). Adaptation to land constraints: Is Africa different? Food Policy, 48, 18-33.

International Society of City and Regional Planners (ISOCARP) (2015). Hungry city, insatiable metropolis. Netherland: ISOCARP.

Jayne, T, Chamberlin, J., \& Headey, D. (2014). Land pressures, the evolution of farming systems, and development strategies in Africa: a synthesis. Food Policy, 48, 1 17.

Lal, R. (2007). There is no such thing as a free biofuel from crop residues. Soil Science Society of America, Past President's Message Archive, 2007. Retrieved from https://www.soils.org/about-society/presidentsmessage/archive/2.

Lasisi, M, Popoola, A. Adediji, A. Adedeji, O., \& Babalola, K. (2017). City expansion and agricultural land loss within the peri-urban area of Osun state, Nigeria. Ghana Journal of Geography, 9(3), 132-163. 
Lwasa, S, Mugagga, F. Wahab, B. Simon, D. Connors, J., \& Griffith, C. (2013). Urban and peri-urban agriculture and forestry: Transcending poverty alleviation to climate change mitigation and adaptation. Urban Climate, 7, 92-106.

Lwasa, S., Wahab, B., Frank,M., Simon, D., Michail, F., Griffith,C.,...\&Adesoji, A (2011). The role of urban and peri-urban agriculture in enhancing food security and climate change resilience in East and West African cities. Final project report for 2011 START grants for global change research in Africa.

Odewumi, S., Awoyemi, O., Iwara, A., \& Ogundele, F. (2013). Farmer's perception on the effect of climate change and variation on urban agriculture in Ibadan metropolis, South-western Nigeria. Academic Journals: Journal of Geography and Regional Planning, 6(6), 209-217.

Popoola, A. A., Ayangbile, O. A., \&Adeleye, B. M. (2015). Assessment of solid waste management systems in Ibadan North, Oyo State using geo-spatial techniques. Ethiopian Journal of Environmental Studies \& Management, 9(6), 666-679.

Pothukuchi, K., \& Kaufman, J. (2000). The food system: A stranger to the planning field. Journal of the American Planning Association, 66(2), 113-124.

Sauer, T., Havlik, P., Schneider, U. A., Schmid, E., Kindermann, G., \& Obersteiner, M. (2008). Agriculture, population, land and water scarcity in a changing world: The role of irrigation. 12th Congress of the European Association of Agricultural Economists - EAAE 2008.

Taiwo, O. (2010). Remote sensing analysis of the spatio-temporal growth of Ibadan city between 1984 and 2006. Ibadan Journal of the Social Sciences, 8(1), 75-90.

Wahab, B., \& Popoola, A. (2018). Climate-induced problems and adaptation strategies of urban farmers in Ibadan. Ethiopian Journal of Environmental Studies \& Management, 11(1), 31-42

Received: $10^{\text {th }}$ August 2018. Accepted: $27^{\text {th }}$ December 2018 